[Radiocarbon, Vol. 18, No. 1, 1976, P. 60-88]

\title{
LYON NATURAL RADIOCARBON MEASUREMENTS VI
}

J EVIN, G MARIEN and Ch PACHIAUDI

Laboratoire de radiocarbone, Départment de Géologie

Université Lyon I

Institut de Physique nucléaire, 69 Villeurbanne, France

INTRODUCTION

This list includes most of the samples measured during 1974 and most of those measured previously but not published in the preceding date list (R, 1975, v 17, p 4-34.)

Up to the end of 1974 no changes were made to counting techniques or to chemical treatments. Two proportional detectors filled with $2 \mathrm{~atm}$ $\mathrm{CO}_{2}$ and a liquid scintillation spectrometer with a $5 \mathrm{~cm}$ lead shield continued to be used. Normally the liquid scintillation vessel is filled with $3 \mathrm{ml} \mathrm{C}_{6} \mathrm{H}_{6}$, but with $10 \mathrm{ml} \mathrm{C}_{6} \mathrm{H}_{6}$, a dating limit of $50,000 \mathrm{yr}$ is possible (see Ly-900, below).

Ages are calculated using 1950 as reference year and the half-life value 5570 . It has not been thought necessary to add $\pm 30 \mathrm{yr}$ uncertainty to this half-life value which is purely conventional. Statistical errors corresponding to one standard deviation include contemporary standard, background, and sample counts.

Generally no age corrections were made either from the $\delta^{13} \mathrm{C}$ values or from the calibration table of dendrochronology. A ${ }^{13} \mathrm{C}$ correction was made for bones using measured $\delta^{13} \mathrm{C}$ values or using $\delta^{13} \mathrm{C}=-20 \pm 4 \%$ according to Lerman (1972).

\section{ACKNOWLEDGMENTS}

We thank Yvette Durand and Gérard Drevon for chemical preparations and most routine operations. We are grateful to J Flandrin, the professors of the Dept of Geology, for their continuous support, and to A Sarrazin and the staff of the Nuclear Physics Institute for their help and technical assistance.

\section{SAMPLE DESCRIPTIONS}

I. GEOLOGIC SAMPLES

A. Samples from fluvial sediments: France, Italy, Spain, and Cambodia

\section{Ly-31. Bokeo, Cambodia}

Modern

Wood from Bokeo Ratanakiri Prov, Cambodia $\left(13^{\circ} 41^{\prime} \mathrm{N}, 107^{\circ} 42^{\prime} \mathrm{E}\right)$.

Coll from a prospecting shaft and subm 1966 by M Lacombe, Ecole Mines, Saint-Etienne. Believed from gravel lying between a basalt flow and volcanic ash. Comment: date proves wood is recent and probably comes from a pit-prop.

\section{Ly-185. Pozo Valls 1, Spain}

AD 1640

$310 \pm 90$

Wood from a mine shaft at Pozo Valls near Hostalrich, Barcelona 
Prov ( $41^{\circ} 44^{\prime}$ N, $2^{\circ} 37^{\prime}$ E). Coll and subm 1967 by B Plus, Paris. Comment: although expected to be interstadial, sample is recent.

Ly-957. Caldaro 2, Bolzano, Italy

AD 1650

Wood from fluvio-glacial drift near Caldaro, Bolzano Prov $\left(46^{\circ} 23^{\prime}\right.$ $\left.\mathrm{N}, 11^{\circ} 15^{\prime} \mathrm{E}\right)$. Coll by M Fresche and subm 1973 by R Vivian, Inst Géog Alpine. Comment: expected age was ca 5000 BP; wood may have been buried by a landslide.

Ly-765. Aubenasson, Drôme AD 1760

$190 \pm 110$

Wood from an erosion slope adjoining a terrace of Drôme $\mathrm{R}$ at Aubenasson, Drôme $\left(44^{\circ} 41^{\prime} \mathrm{N}, 5^{\circ} 8^{\prime} \mathrm{E}\right)$. Coll 1970 and subm 1972 by $\mathrm{M}$ Archambault, Univ Orléans. Comment (MA): date proves wood is modern; possibly a tree root.

\section{Ly-764. Le Petit Signol, Loriol sur Rhône, Drôme AD 1550}

$400 \pm 110$

Wood from a terrace of Rhône $\mathbf{R}$ at Le Petit Signol near Loriol sur Rhône, Drôme $\left(44^{\circ} 41^{\prime} \mathrm{N}\right.$, $4^{\circ} 49^{\prime} \mathrm{E}$ ). Coll 1970 and subm 1972 by $\mathrm{M}$ Archambault. May also be a root that has penetrated into terrace gravel. Comment (MA): date confirms last hypothesis. Wood cannot be used for dating terrace.

\section{Ly-762. Rourebeau, Upaix, Hautes-Alpes}

Fragment of tree trunk from $3.5 \mathrm{~m}$ depth in alluvium of Durance $\mathrm{R}$ at Rourebeau, near Upaix, Hautes-Alpes (44 $\left.14^{\circ} \mathrm{N}, 6^{\circ} 53^{\prime} \mathrm{E}\right)$. Coll and subm 1972 by M Archambault. Comment (MA): date does not agree with expected age; shows enclosing alluvia are recent and overlay retreat alluvia of Würm Glacier.

\section{Ly-901. La Bernardière, Le Grand Serre, Drôme}

$4370 \pm 130$

Wood from highest terrace of Galaure $\mathrm{R}$ at $\mathrm{La}$ Bernardière near

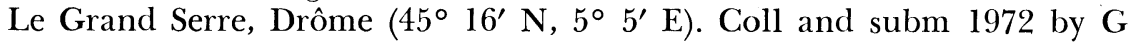
Montjuvent, Inst Dolomieu, Grenoble. Comment (GM): younger than expected, proves rapid alluviation in valley.

\section{Le Grand Rochefort series, Varces, Isère}

Samples from boring in postglacial clayey sediments of Grenoble region at Le Grand Rochefort near Varces, Isère (45 $51^{\prime} \mathrm{N}, 5^{\circ} 40^{\prime} \mathrm{E}$ ). Coll and subm 1972 by G Montjuvent. Dated to determine rate of postglacial alluviation.

\section{Ly-902. Grand Rochefort de Varces, bois}

$4090 \pm 130$

Wood from $12 \mathrm{~m}$ depth embedded at base of a clayey layer. 


\section{Ly-903. Grand Rochefort de Varces, tourbe

Peat from a sandy clayey layer.

General Comment (GM): dates agree with prehistoric and sedimentologic data.

\section{Ly-969. Voiron, Isère}

$9900 \pm 160$

7950 вC

Calcareous tufa found under foundations of a house in Voiron, Isère $\left(45^{\circ} 21^{\prime} \mathrm{N}, 5^{\circ} 34^{\prime} \mathrm{E}\right)$. Coll and subm 1974 by G Montjuvent. Comment (GM): some paleosols are embedded in tufa. Although original ${ }^{14} \mathrm{C}$ value for this type of material is doubtful, as expected, date indicates beginning of post-Würmian period.

\section{Ly-876. Tuf des Barbiers, Lazer, Hautes-Alpes}

$10,900 \pm 280$

Calcareous tufa, from bank of Les Barbiers R near Lazer, HautesAlpes $\left(44^{\circ} 21^{\prime} \mathrm{N}, 5^{\circ} 50^{\prime} \mathrm{E}\right)$. Coll and subm 1973 by M Archambault. Tufa overlies a clayey layer with wood previously dated, Ly-555: $9250 \pm$ 190 (R, 1973, v 15, p 516). Comment (MA): age considered maximum; using $80 \%$ modern as ${ }^{14} \mathrm{C}$ original value for this continental calcareous material, date, са 9000 вР is obtained, which confirms previous value.

B. Peat bog samples: France and Italy

Ly-819. Val di Sangro 1 Pescara, Italy

$2740 \pm 110$

$790 \mathrm{BC}$

Carbonaceous earth from $18 \mathrm{~m}$ depth in boring in lacustrine deposits in Val di Sangro, Pescara Prov $\left(47^{\circ} 2^{\prime} \mathrm{N}, 14^{\circ} 21^{\prime} \mathrm{E}\right.$ ) (Del Prete \& Gerrichio, 1974). Coll 1973 by M Del Prete and subm 1973 by G S Tazioli, Fac ingegneria, Univ Bari, Italy. Comment (GST): date confirms paleontologic and geologic data.

\section{L'Isle sur la Sorgue series, Vaucluse}

Clayey peat from 2 layers in a road drain near L'Isle sur la Sorgue, Vaucluse $\left(45^{\circ} 55^{\prime} \mathrm{N}, 5^{\circ} 2^{\prime} \mathrm{E}\right)$. Coll 1972 and subm 1973 by $\mathrm{H}$ Triat, Lab Palynol, Univ Marseille III.

\section{Ly-911. L'Isle sur la Sorgue 210}

$4450 \pm 150$

Expected climatic phase: Sub-Boreal, $210 \mathrm{~cm}$ above reference level.

\section{Ly-910. L'Isle sur la Sorgue, 10}

$6880 \pm 180$

$10 \mathrm{~cm}$ above reference level. Expected climatic phase: end of Atlantic. General Comment (HT): both dates are older than expected. Ly-910 places the Quercus pabescens Willd increase in pollen diagram in middle of Atlantic period, whereas Ly-911 dates an early deforestation at Sub-Boreal. 


\section{Le Plan du Laus, Sondage 772 series, Alpes de Haute Provence}

Peat from several layers in boring in Le Plan du Laus peat bog near

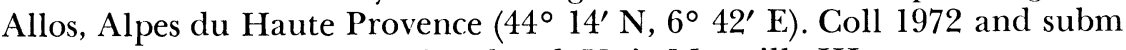
1973 by J L de Beaulieu, Lab Palynol, Univ Marseille III.

Ly-995. Plan du Laus, Sondage 772, $245 \mathrm{~cm}$

$5820 \pm 150$

Marks beginning of Sub-Boreal with start of Larix pollen curve.

Ly-960. Plan du Laus, Sondage 772, 305em

$7310 \pm 140$

Marks Abies maximum in Atlantic period.

5360 BC

$8630 \pm 200$

Ly-996. Plan du Laus, Sondage 772, $463 \mathrm{~cm}$

$6680 \mathrm{BC}$

Marks middle of Boreal before beginning of Abies.

$8320 \pm 180$

Ly-997. Plan du Laus, Sondage $772,475 \mathrm{~cm}$

6370 BC

Same layer as Ly-996.

Ly-998. Plan du Laus, Sondage $772,525 \mathrm{~cm}$

$8970 \pm 210$

7020 BC

Marks preponderance of Pinus at beginning of Boreal.

\section{Ly-961. Plan du Laus, Sondage 772, $585 \mathrm{~cm}$}

$8820 \pm 370$

Same layer as Ly-998.

$6870 \mathrm{BC}$

General Comment (JLB): all results agree with stratigraphy and expected date range. Pollen diagrams show Abies occurred at beginning of Atlantic period as usual in all W Alps. Larix forest in area of site grew at end of Atlantic period.

\section{Lac de Creno series, Corsica}

Peat from 2 neighboring boreholes ( 1 and 6) in Lac de Creno peat bog near Orto, Corsica $\left(43^{\circ} 12^{\prime} \mathrm{N}, 8^{\circ} 56^{\prime} \mathrm{E}\right)$. Coll 1973 and subm 1974 by M Reille, Lab Palynol, Univ Marseille III (Reille, 1975).

\section{Ly-915. Lac de Creno, Sondage 1, 45 to $50 \mathrm{~cm} \quad$ AD 300}

$1650 \pm 160$

Young peat from 45 to $50 \mathrm{~cm}$ depth. Beginning of Fagus silvatica increase on slope of Rotondo Massif, Sub-Atlantic. Comment (MR): results confirm Ly-964: $1550 \pm 65$ BP (unpub) which dates same event in pollen diagram of neighboring Borehole 5.

$5600 \pm 230$

Ly-965. Lac de Creno, Sondage 6, 417 to $422 \mathrm{~cm} 3650 \mathrm{BC}$

Peat and wood from 417 to $422 \mathrm{~cm}$ depth. End of Atlantic period. Beginning of decline of Erica arborea and Alnus glutinosa in Corsica. 
Ly-912. Lac de Creno, Sondage 6, 505 to $510 \mathrm{~cm} 6050 \mathrm{BC}$

Greenish organic clay from 505 to $510 \mathrm{~cm}$ depth. According to pollen spectra, layer dates from beginning of Atlantic period. Comment (MR): because of a hiatus corresponding to all Boreal period, layer overlies Pre-Boreal, which probably causes date to be too old. A comparable layer, but one stratigraphically more extended in Atlantic period, gives a normal younger date in Lac de Creno Borehole 2, Ly-643: $7570 \pm 120$ вP (unpub).

Ly-914. Lac de Creno, Sondage 6, 515 to $525 \mathrm{~cm} \quad \mathbf{8 4 7 0} \pm 260$

Greenish organic clay from 515 to $525 \mathrm{~cm}$ depth. End of Dryas III or beginning of Pre-Boreal. Comment (MR): as in Greece (Bottema, 1974, GrN-4875: 10,190 $\pm 90 \mathrm{BP}$ ) date marks fall of Artemisia pollen curve.

$10,250 \pm 420$

Greenish organic clay from 533 to $540 \mathrm{~cm}$ depth. End of Dryas III, beginning of fall of Artemisia pollen curve. Comment (MR): Ly-914 and -964 appear stratigraphically inverted but remain in statistical ranges.

\section{Ly-913. Lac de Creno, Sondage 6, $12,080 \pm 230$ 540 to $550 \mathrm{~cm}$ \\ 10,130 BC}

Greenish organic clay from 540 to $550 \mathrm{~cm}$. Comment (MR): minimum of Artemisia pollen curve, attributed either to a wet climatic fluctuation during Dryas III period or Alleröd period; in both cases, date is too old.

C. Samples from glacial or periglacial sediments: France and Switzerland

\section{Entre deux Eaux series, Termignon, Savoie}

Wood from alt $2100 \mathrm{~m}$ above present timberline at Entre Deux Eaux near Termignon, Savoie $\left(45^{\circ} 22^{\prime} \mathrm{N}, 6^{\circ} 50^{\prime} \mathrm{E}\right)$. Coll by C Ponson and subm 1973 by R Vivian.

Ly-956. Entre Deux Eaux 2

$450 \pm 200$

Wood splinter from an old chalet in Dôme de Chassefort, Alpage.

\section{Ly-955. Entre Deux Eaux 1}

$420 \pm 180$

Wood embedded in a peat bog near Les Richard, Alpage.

General Comment (RV): both dates indicate arboreal vegetation on slopes of Dôme de Chassefort during historic period, and demonstrate rapid peat bog growth.

\section{Ly-891. Saint Martin de Belleville, Savoie}

$4470 \pm 150$ 2220 BC

Fragment of a tree trunk embedded in a peat bog at alt $1970 \mathrm{~m}$ in glacial alluvium of Peclet-Thorens Glacier near Saint Martin de Belle- 
ville, Savoie $\left(45^{\circ} 22^{\prime} \mathrm{N}, 6^{\circ} 30^{\prime} \mathrm{E}\right)$. Coll and subm 1973 by R Vivian. Comment (RV): agrees with expected age and indicates timberline rise previously dated in France and Switzerland (see R, 1975, v 17, p 7).

\section{Ly-877. Praz Rodet, Le Brassus, $\quad 12,270 \pm 210$ Vaud, Switzerland \\ $10,250 \mathrm{BC}$}

Fragments of mammoth tusk (Elephas primigenius) from Praz-Rodet near Le Brassus, Vaud (46 $\left.35^{\prime} \mathrm{N}, 6^{\circ} 13^{\prime} \mathrm{E}\right)$. Coll 1969 and subm 1973 by M Weidman, Geol Mus, Lausanne. Complete mammoth skeleton was found at alt $1070 \mathrm{~m}$, at $1 \mathrm{~m}$ depth in redeposited morainic sediments. May be contemporaneous with last retreat of Würm glacier (Aubert, 1970). Expected age: 10,000 to 15,000 BC. Skeleton is now exhibited in Lausanne Geol Mus (Weidmann, 1969; 1974). Comment (MW): corresponds well with expected age; shows end melting of Jura ice cap occurred fairly early.

\section{Ly-1002. Vautubière $\mathrm{n}^{\circ}$ 3-13, Bouches du Rhône 28,150 BC}

Charcoal from Level 13 in Coudoux quarry in Vautubière valley near Lançon, Bouches du Rhône (43 $\left.34^{\prime} \mathrm{N}, 5^{\circ} 13^{\prime} \mathrm{E}\right)$. Coll 1972 and subm 1974 by $\mathrm{P}$ Ambert, Lab géog phys, Aix Marseille II. Level 13 lies between 2 series of Würmian eolian sediments (Ambert et al, 1974). 1900

Comment (PA): in statistical range of Ly-769: 31,900 \pm 1500 , confirms attribution to beginning of Würm III ( R, 1975, v 17, p 9).

\section{Ly-875. Les Sauziers, Lazer, Hautes-Alpes \\ $31,100 \pm 1000$}

Fragment of tree trunk rooted in slope of a hill overlain by a moraine, at Les Sauziers near Lazer, Hautes-Alpes (44 $\left.21^{\prime} \mathrm{N}, 5^{\circ} 52^{\prime} \mathrm{E}\right)$. Coll 1967 and subm 1973 by M Archambault (1968). Comment (MA): confirms previous measurement, I-5023: 31,450 $\pm 1300 \mathrm{BP}$ and attributes a Würm III or IV age to moraine unless enclosing sediments were redeposited from moraine as slope deposits.

\section{Verinay series, Ain}

Wood from upper and lower part of an interglacial series lying

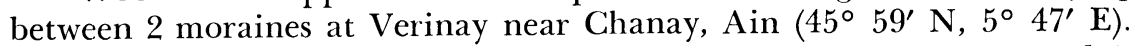
Coll and subm 1968 (Verinay I) or 1970 (Verinay II) by J Evin and $\mathbf{P}$ Donze, Geol Dept, Univ Lyon I.

Ly-236. Verinay I, sommet

From upper layer.

$26,250 \pm 2200$

Ly-235. Verinay I, base

2300

From lower layer.

$33,600 \pm 1350$ 
Ly-338. Verinay II, sommet

From upper layer.

Ly-337. Verinay II, base

$\geqslant 33,600$

General Comment (PD): comparison of Vérinay I and Vérinay II results shows insufficient chemical treatment of Verinay I samples infinite; age implies sediments are not Würm III $/ \mathbf{I V}$. To demonstrate that it is not Würm II/III interstadial, other measurements will be made with a more precise detector. All the geologic features of the sediments suggest, rather, the Riss/Würm interglacial according to geologic data in France and Switzerland (Donze et al, 1971).

Ly-959. Col du Pignon, Aspres sur Buech, Hautes-Alpes $\geqslant 32,700$

Small pieces of charcoal from clayey lacustrine sediments at Le Pignon Pass near Aspres sur Buech (44 $\left.30^{\prime} \mathrm{N}, 5^{\circ} 45^{\prime} \mathrm{E}\right)$. Coll 1972 by M Duluc and subm 1973 by $\mathbf{G}$ Montjuvent. Comment (GM): date does not invalidate Riss/Würm interglacial attribution.

Ly-900. La Flachère, Isère

Wood from clayey layer with lignite lying between 2 moraines in a

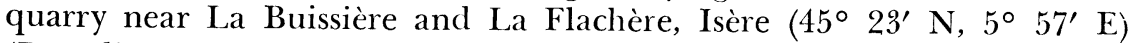
(Bourdier, 1961). Coll and subm 1972 by G Montjuvent. Dated with $10 \mathrm{ml}$ benzene and $1 \mathrm{ml}$ scintillating toluene in especially shielded spectrometer. Comment (GM): shows practical limit of dating; seems to exclude a Würm II/III interstadial attribution to the lignite; it can only be either Würm I/II or Riss/Würm.

D. Bone samples from grottoes: France

\section{Ly-820. Le Plo Del May, Verdalle, Tarn}

$28,400 \pm 700$

Bone from clayey layer with rich fauna underlying a stalagmitic floor in Plo del May grotto near Verdalle, Tarn $\left(43^{\circ} 20^{\prime} \mathrm{N}, 2^{\circ} 9^{\prime} \mathrm{E}\right)$. Coll 1973 by R P Pierre-Marie and subm 1973 by F Prat, Inst Quaternaire, Bordeaux. Comment (FP): despite fairly old age, bones still contained $8 \%$ organic matter, perhaps clue to upper stalagmitic floor that reduced water infiltrations. Result attributes fauna to Würm III concurring with sedimentologic and paleontologic data (Laville et al, 1972).

\section{Jaurens series, Corrèze}

Bones from Jaurens grotto near Nespouls, Corrèze $\left(45^{\circ} 2^{\prime} \mathrm{N}, 1^{\circ} 41^{\prime}\right.$ E). Coll and subm by C Guerin, 1969 \& 1972, Geol Dept, Univ Lyon I. Bones were embedded in clayey floor of grotto, assoc with rich Late Würm fauna (Guerin, 1970).

\section{Ly-359. Jaurens 1}


Ly-892. Jaurens 2

28,400 BC

Both dates agree statistically and indicate beginning of Würm III. Although different, Jaurens and Siréjol (see below) fauna are contemporaneous.

\section{Siréjol series, Lot}

Bones from Siréjol grotto, near Gignac, Lot $\left(44^{\circ} 59^{\prime} \mathrm{N}, 1^{\circ} 29^{\prime} \mathrm{E}\right)$. Coll 1971 and 1973 by M Philippe and subm 1972 and 1973 by C Guérin. Grotto contains filling of fossiliferous clayey lumps. It is presently entered only through a narrow gallery which opens 1st into a small cave containing Hallstatt burials. Inside the main cave, underlying the entrance of the gallery, is a little rubbish-cone whose sediments seem younger than main clayey filling (Guérin \& Philippe, 1971).

\section{Ly-928. Siréjol, sépulture $n^{\circ} 4$}

$2590 \pm 140$

From Hallstatt sepultures.

Ly-927. Siréjol, petit éboulis $n^{\circ} 3$

640 вC

From rubbish-cone.

$4290 \pm 350$

2340 вC

From rubbish-cone.

1800

Ly-614. Siréjol, remplissage principal $n^{\circ} 1$

$31,300 \pm 1600$

From main filling.

29,350 вс

Ly-767. Siréjol, remplissage principal $n^{\circ} 2$

1600

$27,150 \mathrm{BC}$

From main filling.

General Comment (CG): Ly-928 confirms archaeologic attribution of burial. Ly-927 confirms rubbish-cone is younger than main clayey filling. Ly-614 and -767 are in statistical agreement and their average is: Ly-614/ 767: $30,100 \pm 1200 \mathrm{BP}$, indicating beginning of Würm III, consistent with faunal study.

\section{Ly-979. Nauterie, La Romieu, Gers}

$\geqslant \mathbf{2 9 , 0 0 0}$

Bones from Level 2 in Nauterie Grotto near La Romieu, Gers $\left(44^{\circ}\right.$ $2^{\prime} \mathrm{N}, 0^{\circ} 30^{\prime} \mathrm{E}$ ). Coll and subm 1973 by $\mathrm{F}$ Prat et $\mathrm{C}$ Thibault, Inst Quaternaire, Univ Bordeaux I. Clayey layer enclosing bones is overlain by a stalagmitic floor, the upper part of the grotto filling. Comment (FP \& CT): older than expected; grotto was probably filled before Würm III.

E. Shell samples from coastal sediments: Italy, Senegal and Mauritania Sibari series, Italy

Samples from Casa Bianca at Sibari, Calabria, Italy $\left(39^{\circ} 47^{\prime} \mathrm{N}, 16^{\circ}\right.$ $27^{\prime}$ E). Coll 1973 by G Melidoro and subm 1973 by G S Tazioli. 
$860 \pm 120$

Ly-878. Sibari 1

Cerastoderma shells.

AD 1090

$2330 \pm 120$

Ly-879. Sibari 2

Fragment of a tree trunk (Tamarix Gallia-Webb).

General Comment (GM): both measurements made to confirm archaeologic dating of old buried town of Sibari and to study subsidence process of the coastal plain (Guerricchio \& Melidoro, 1975). Results approximate subsidence and help date archaeologic layers.

\section{Lac Retba series, Sénégal}

Shells from marine terrace and kitchen midden on Retba lakeside $28 \mathrm{~km}$ NE Dakar, Sénégal $\left(14^{\circ} 50^{\prime} \mathrm{N}, 17^{\circ} 13^{\prime} \mathrm{W}\right)$. Coll and subm 1974 by $\mathbf{P}$ Elouard, Dept Géol, Univ Lyon I.

\section{Ly-887. Lac Retba, base, kitchen} midden WS 4

$680 \pm 130$

Arca senelis and Dorinia sp.

\section{Ly-888. Lac Retba, sommet, kitchen midden WS 5}

Arca senelis.

Ly-889. Lac Retba, poterie WS 6 AD 1270

Small amount of charred organic matter included in pottery.

\section{Ly-885. Lac Retba, terrasse WS 2}

Arca senelis.

\section{Ly-886. Lac Retba, sable blane WS 3}

Arca senelis and Dorinia sp.

General Comment (PE): dates prove that salt-water lagoon sediments around Retba Lake are recent and contemporaneous with human occupation. A similar date for a shell-fishing settlement was previously dated in mid-west Sénégal at Bangalaré Bolon in Salaun $\mathrm{R}$ Delta (see 4 Ly dates: $\mathrm{R}, 1975, \mathrm{v} 17, \mathrm{p} 13)$. Retba lake is at present very salty due to evaporation since closing, $<1000$ yr ago.

\section{Ly-890. Lac Tanma, Sénégal}

$2630 \pm 110$

Arca senelis from $.40 \mathrm{~m}$ depth in a marine terrace near Tanma lake, $45 \mathrm{~km}$ NW Dakar $\left(14^{\circ} 54^{\prime} \mathrm{N}, 17^{\circ} 5^{\prime} \mathrm{W}\right)$. Coll and subm 1974 by $\mathrm{P}$ Elouard. Comment (PE): younger than expected, shows Tanma lake, like Retba Lake, remained in connection with the sea until recently. Such a recent age for marine sediments is found also in uplifted beaches 
in Dakar region at Cap Manuel: T-725: $2470 \pm 70 \mathrm{BP}$ (unpub) and at Les Almandies beach: Ly-812: $3130 \pm 240$ вР (R, 1975, v 17, p 14).

\section{Ly-884. Sondage en mer, Baie de Han WS15}

$4280 \pm 160$

2330 вс

Pitaria tumens from -4 to $-5 \mathrm{~m}$ layer in cuttings of offshore boring at $8.5 \mathrm{~m}$ depth in Han bay, between Mbao and Tiaroye sur Mer, $15 \mathrm{~km}$ SE Dakar, Sénégal $\left(14^{\circ} 40^{\prime} \mathrm{N}, 17^{\circ} 20^{\prime} \mathrm{W}\right)$. Coll and subm 1973 by $\mathbf{P}$ Elouard. Comment (PE): date corresponds to late Nouakchottian and shows that sedimentation rate in Han bay is low.

\section{Rao Peul and Gandon series, Mauritania}

3 pairs of shell samples from tops and bases of marine terraces with Arca senelis near Rao Peul (15 $\left.54^{\prime} \mathrm{N}, 16^{\circ} 26^{\prime} \mathrm{W}\right)$, Gandon II $\left(15^{\circ} 57^{\prime} \mathrm{N}\right.$, $\left.16^{\circ} 26^{\prime} \mathrm{W}\right)$, or Gandon III $\left(15^{\circ} 56^{\prime} \mathrm{N}, 16^{\circ} 25^{\prime} \mathrm{W}\right)$, near Saint Louis Sénégal. Coll 1973 by J Monteillet, Saint-Louis and subm 1974 by P Elouard.

\section{Ly-982. Rao Peul sommet NK a 1}

$4670 \pm 120$

Arca senelis, alt $+2 \mathrm{~m}$.

\section{Ly-983. Rao Peul base NK e 5}

Arca senelis, alt $+0.4 \mathrm{~m}$.

\section{Ly-986. Gandon III sommet NK a 1}

2720 BC

Arca senelis, alt $+2 \mathrm{~m}$.

Ly-987. Gandon III base NK e 5

$5250 \pm 120$

3300 BC

Arca senelis, alt $+0.7 \mathrm{~m}$.

Ly-984. Gandon III sommet NK a 1

$4720 \pm 140$

2770 вC

Tymponotouns sp; alt ca $+2 \mathrm{~m}$.

\section{Ly-985. Gandon II base NK C4}

$5590 \pm 140$ 3640 BC

Arca senelis alt $+1.2 \mathrm{~m}$.

General Comment (PE): from 3 pairs of results, date of base is са 5500 вР and corresponds to maximal Nouakchottian transgression (Elouard, 1968); see also T-404: $5570 \pm 120$, and Ly-350: $5510 \pm 120$ вр from Nouakchott (R, 1975, v 17, p 15). 3 pairs of dates for top decrease toward $\mathrm{NW}$ as expected, marking beginning of regression, seems earlier than expected.

\section{Khant de Saint-Louis series, Sénégal}

Arca senelis, from a kitchen midden, a sand dune and a marine terrace overlain by another kitchen midden in Le Marigot de Khant, $15 \mathrm{~km}$ E of Saint-Louis, Sénégal $\left(16^{\circ} 8^{\prime} \mathrm{N}, 16^{\circ} 27^{\prime} \mathrm{W}\right)$. Coll 1971 and 
subm 1974 by $P$ Elouard. Le Marigot de Khant formed a deep lagoon, open to the sea.

\section{Ly-988. Saint-Louis SL 10}

Shells from kitchen midden overlying marine terrace.

\section{Ly-989. Saint-Louis SL 11}

Shells from marine terrace.

Ly-990. Saint-Louis SL 13

Shells from kitchen midden overlying dune.
$5340 \pm 120$ 3390 BC

$5410 \pm 120$

3460 вC

$5650 \pm 140$

$\mathbf{3 7 0 0}$ BC

General Comment (PE): 3 results indicate that terrace and kitchen middens are Nouakchottian. Small difference between Ly-990 (a little older) and 2 other dates shows that fishermen settlement followed sealevel regression; comparable dates for human occupation were previously found in regions more open to the sea, eg, at Rao terrace, T-463: $5470 \pm 110$ вр (Elouard et al, 1966).

\section{ARCHAEOLOGIC SAMPLES}

A. Bronze to Historic periods

Ly-870. Tumulus de Mijoux, La Faucille, Ain

$\delta^{14} \mathrm{C}=+\mathbf{0 . 2 5 \%} \begin{array}{r}\text { Modern } \\ \pm \mathbf{1 . 4 0}\end{array}$

Wood from floor in an Iron age tumulus at Mijoux near, La Faucille, Ain $\left(46^{\circ} 4^{\prime} \mathrm{N}, 6^{\circ} 0^{\prime} \mathrm{E}\right)$. Coll and subm 1973 by M Labarrère, Gex. Comment (ML): date proves that tumulus was used recently as hunting shelter or look-out post.

\section{Ly-905. Saint-Jacut de la Mer, Côtes du Nord}

$365 \pm 130$

Human skull from a common grave in an old cemetery near SaintJacut de la Mer, Côtes du Nord (48 $\left.36^{\prime} \mathrm{N}, 2^{\circ} 12^{\prime} \mathrm{W}\right)$. Coll 1970 by M Thebault and subm 1973 by J C Ménès, Bernin, Isère. Expected age: from 5 th century AD to time of French Revolution (Lemasson, 1912). Comment (JCM): grave must be from cemetery of Abbey of Saint-Jacut, whose site was unknown till now.

\section{Ly-871. Clairière de Girieux, Proveysieux, Is̀̀n \\ $575 \pm 125$}

Charcoal from hearth $45 \mathrm{~cm}$ deep, assoc with supposed Chalcolithic industry in an open air site at Girieux quarry near Proveysieux Isère $\left(45^{\circ} 15^{\prime} \mathrm{N}, 5^{\circ} 40^{\prime} \mathrm{E}\right)$. Coll 1972 and subm 1973 by M Malenfant, Grenoble. Comment (MM): date proves hearth is not contemporary with industry. Either it was dug into archaeologic layers or industry comes from elsewhere. 
Ly-898. Soyons, Ardèche

$1510 \pm 220$

Human bones from $4 \mathrm{~m}$ depth in excavation for a road at $\mathrm{S}$ Soyons, Ardèche $\left(44^{\circ} 53^{\prime} \mathrm{N}, 4^{\circ} 5^{\prime} \mathrm{E}\right)$. Coll 1973 by $\mathrm{R}$ Martin, Valence, and subm by $\mathrm{P}$ Elouard. From $2 \mathrm{~m}$ under a Gallo-Roman layer; expected age: 2500 to 1000 вс. Comment: date does not agree with expected age, indicates either a landslide of Gallo-Roman deposits or a deep inhumation.

\section{Néco $178 \pm 120$$$
1770 \pm 120
$$

Human bones from Gallo-Roman sarcophagus from cemetery around foundations of several Paleochristian to Middle age churches in Les Macchabés St, near Saint-Just, Lyon, Rhône $\left(45^{\circ} 46^{\prime} \mathrm{N}, 4^{\circ} 50^{\prime} \mathrm{E}\right)$. Coll and subm 1972 by J F Reynaud, Univ Lyon II. Comment (JFR): considering statistical range, sarcophagus was not reused in Carolingian time ca AD 800 as presumed).

\section{Grigny series, Rhône}

Wood from handles of metallic objects dredged from Rhône $\mathrm{R}$ at Grigny, Rhône $\left(45^{\circ} 36^{\prime} \mathrm{N}, 4^{\circ} 47^{\prime} \mathrm{E}\right)$. Coll 1970 and subm 1971 by $\mathrm{G}$ Chapotat, Centre recherche Archéol, Vienne, Isère.

\section{Ly-954. Grigny RH 43}

$2160 \pm 160$

Fragment of Abies from bargeman's iron boot hook, attributed to La Tène period or younger.

\section{Ly-953. Grigny RH 15}

$2200 \pm 320$

Fragment of Buxus or Cornus from a bronze staff attributed to Bronze age, but this type of staff may also be younger.

\section{Ly-952. Grigny RH 12}

$3070 \pm 110$

Fragment of Fraxinus from a bronze staff "à oeillet en aillerons médians" attributed to Bronze age (Chapotat, 1971).

General Comment (GC): Ly-952 indicates beginning of Late Bronze or end of Middle Bronze age, as normal for this type of staff; Ly-953 is 500 yr too young for Bronze age but may indicate that staff was used later; Ly-954 proves this type of boot hook, still used during the last century, remained unchanged for $2000 \mathrm{yr}$.

\section{Ly-881. Mehatze, Unité B, Itassou, $\quad 2380 \pm 130$ Pyrénées Atlantiques \\ $430 \mathrm{BC}$}

Charcoal from clayey sediments from an incineration cist in Mehatze necropolis near Itassou, Pays Basque, Pyrénées Atlantiques $\left(43^{\circ} 18^{\prime} \mathrm{N}\right.$, $\left.1^{\circ} 25^{\prime} \mathrm{W}\right)$. Coll and subm 1973 by C Chauchat, Inst Quaternaire, Bordeaux. No industry has been found in these graves; their attribution to lst Iron age depends on architectural comparisons. Comment (CC): 
seems to confirm attribution to 1st Iron age; sample comes from last built part of site.

\section{Ly-904. Lezoux, Puy de Dôme}

Human bones from a Gallo-Roman necropolis at Lezoux, Puy de Dôme $\left(45^{\circ} 49^{\prime} \mathrm{N}, 3^{\circ} 22^{\prime} \mathrm{E}\right)$. Coll by $\mathrm{H}$ Vertet and subm 1973 by $\mathrm{M}$ Dumontet, Dir Antiquités historiques, Clermont Ferrand. Site includes 2 cemeteries: from Protohistoric period (some centuries BC), the other from the Roman period ( 1 st to 4 th centuries AD). Bones were expected from younger graves cutting through both cemeteries. Comment: despite submitter's opinion and archaeologic evidence, bones probably come from Protohistoric period, or at latest, beginning of Roman.

\section{Vendenheim series, Bas Rhin}

Charcoal from 2 graves in Vendenheim site, Bas Rhin $\left(48^{\circ} 40^{\prime} \mathrm{N}\right.$, $7^{\circ} 42^{\prime} \mathrm{E}$ ). Coll and subm 1973 by A Thevenin, Dir antiquités préhistoriques, Strasbourg.

\section{Ly-867. Vendenheim $n^{\circ} 2$}

$2370 \pm 100$

Samples from a grave $1.80 \mathrm{~m}$ deep, assoc with La Tène or Bronze industry. Coll 1973 by J Sainty. Comment (AT): date indicates La Tène period.

\section{Ly-866. Vendenheim $n^{\circ} 1$}

$4870 \pm 110$

Sample from a grave $1.50 \mathrm{~m}$ deep with industry of Lingolsheim group type (between Michelsberg and Poinçonné types). Coll 1973 by F Wendling. Comment (AT): date a little older than expected but feasible. Nearest ${ }^{14} \mathrm{C}$ result in region is from Level $\mathrm{X}$ at La Baume de Gonvillars, Haute Saône, assoc with industry of Rössen-Michelsberg type, Gif-466: $5000 \pm 250(\mathrm{R}, 1970, \mathrm{v} 12, \mathrm{p} 429)$ which, as normal, is a little older.

\section{Ly-880. Grotte de la Balme, Sollières-Sardières, Savoie \\ $2450 \pm 110$ 500 вс}

Charcoal from hearths in La Balme Grotto at Sollières-Sardières, Savoie $\left(45^{\circ} 16^{\prime} \mathrm{N}, 6^{\circ} 48^{\prime} \mathrm{E}\right)$. Coll and subm 1973 by A Bocquet, Inst Dolomieu, Grenoble. Hearths were a few $\mathrm{cm}$ from late Bronze II ceramics (ca $900 \mathrm{BC}$ ) and included some Early Bronze or Chalcolithic pottery. Comment (AB): too young for Late Bronze II, even with $3 \sigma$ statistical range, so date indicates subsequent use of site that contaminated Protohistoric hearth.

\section{Ly-872. Les Champs vieux 72 Z'3 Haute-Loire}

$$
2870 \pm 100
$$

Charcoal assoc with carbonaceous earth from Les Champs-Vieux site near Solignac sur Loire $\left(44^{\circ} 58^{\prime} \mathrm{N}, 3^{\circ} 42^{\prime} \mathrm{E}\right)$. Coll 1972 by R Liabeuf and subm 1973 by M Philibert, Le Puy. Samples were in group at level of Late Neolithic industry, comparable to one previously measured at 
Le Rond du Lévrier site, Salette, Hauteloire; Ly-194: $3370 \pm 210$ BP ( R, 1971, v 13, p 59). Comment (MP): much younger than expected; probably proves charcoal came from overlying Late Bronze occupation level and fell through very aerated upper layer (Philibert \& Moser, 1974.) Such contamination by charcoal from overlying layers is frequent in shelters in regions with basaltic formations, see eg, upper layers in Longetraye site, Hauteloire (R, 1975, v 17, p 22).

\section{B. Neolithic and Mesolithic periods}

$$
3910 \pm 100
$$

\section{Ly-895. Tumulus "Dolmen" des Grèzes, Souillac, Lot 1960 BC}

Human bones from main room of dry-stone dolmen at "Les Grèzes", near Souillac, Lot $\left(44^{\circ} 55^{\prime} \mathrm{N}, 1^{\circ} 26^{\prime} \mathrm{E}\right)$. Coll and subm 1973 by J P Girault, Cugnaux, Haute Garonne. Dolmen is a round dry stone tumulus containing a rectangular room, which continues without narrowing up to tumulus inner edge with only large stone to separate room and corridor. This monument cannot be compared to any other. Bones are assoc with arrowheads and pearls and grave is presumed Chalcolithic. Comment (JPG): date agrees perfectly with industry.

Ly-896. Champs sur Yonne, Yonne

$4150 \pm 180$

Human bones from open-air sepulture $1 \mathrm{~m}$ deep at Champs sur Yonne, Yonne $\left(47^{\circ} 44^{\prime} \mathrm{N}, 3^{\circ} 36^{\prime} \mathrm{E}\right)$. Coll 1965 and subm 1973 by F Poplin; assoc with attractive campaniform vase. Comment (FP): date conforms to Chalcolithic attribution.

\section{Les Baigneurs series Charavines, Isère}

Samples from 2 levels and several places in coastal submerged sta, Les Baigneurs, in Paladru Lake at Charavines, Isère $\left(45^{\circ} 25^{\prime} \mathrm{N}, 5^{\circ} 30^{\prime} \mathrm{E}\right)$. Coll and subm by A Bocquet.

\section{Ly-792. Les Baigneurs, (Cha 3) Pirogue A}

$4190 \pm 150$

Wood from a monoxyl barge lake mud at level of upper archeologic layer. Coll and subm 1972. Comment (AB): this style of barge remained unchanged for several millennia. Result indicates barge is contemporary with coastal sta.

Ly-908. Les Baigneurs (Cha 6), Pilotis no $131 \quad 2590$ BC

Fragment of pile, supposedly from last occupation of site. Coll 1973.
Ly-793. Les Baigneurs (Cha 2), $\quad \mathbf{4 4 4 0} \pm 230$ Pilotis triangle I-7
2490 BC

Fragment of pile, supposedly from 1st occupation of site. Coll 1972.

$\begin{array}{ll} & 4230 \pm 130 \\ \text { Ly-907. Les Baigneurs (Cha 5), Pilotis no } 127 & 2280 \mathrm{BC}\end{array}$

Fragment of pile, supposedly from 1st occupation of site. Coll 1973. May be contemporaneous with Cha 4: Ly-906. 
$4360 \pm 130$

Charcoal from lowest layer. Coll 1972.

\section{Ly-909. Les Baigneurs (Cha 7), Couche B 1}

$9940 \pm 130$

Weathered twigs and bark called "lacustrine dung" from upper Layer B 1, in which was embedded a flint dagger with a handle in form of discoidal pommel.

\section{Ly-906. Les Baigneurs (Cha 4), Couche B 3}

$4100 \pm 120$

Charcoal from lower Layer B 3.

General Comment (AB): all results are statistically very close and suggest occupation ca 2300 to $2400 \mathrm{BC}$, closely agreeing with other results from Late Neolithic or Chalcolithic coastal sta, as: Ly-688: $4600 \pm 120$ from lake Aiguebelette, Savoie, or Ly-851: $4070 \pm 140$ from lake Clairvaux, Jura, which are a little younger ( $R, 1975, \mathrm{v} 17, \mathrm{p} 19)$. But it remains impossible to distinguish typologically which layer had 2 or more different occupations. On the other hand ${ }^{14} \mathrm{C}$ ages might be slightly modified by true age of tree trunks when used in construction (Ly-908, $-799, \mathrm{eg}$ ), and samples were not necessarily in outer part of piles. Ly-909 is much too old (at least $5500 \mathrm{yr}$ ); result is aberrant and unexplained.

\section{Ly-980. La Balme les Grottes, Isère \\ $5270 \pm 140$ 3320 BC}

Small human bones from an ossuary in Locus III, upper gallery, La Balme grotto, La Balme-les-Grottes, Isère $\left(45^{\circ} 51^{\prime} \mathrm{N}, 5^{\circ} 19^{\prime} \mathrm{E}\right)$. Coll 1969 by J Reymond, and subm 1974 by A Bocquet. Sample assoc with Late Neolithic industry. Comment (AB): date is a little older than expected and suggests Middle Neolithic, agreeing with a potsherd of Chassean tradition from neighboring loc. Common ossuaries are generally from Late Neolithic time.

\section{Les Tumulus de Bougon series, Deux-Sèvres}

Human bones from 2 funerary rooms in Megalithic necropolis, "Les Tumulus", near Bougon, Deux-Sèvres $\left(46^{\circ} 21^{\prime} \mathrm{N}, 0^{\circ} 11^{\prime} \mathrm{W}\right)$. Coll and subm 1973 by J P Mohen, Mus Antiquités Natl Saint-Germain en Laye. These 2 dolmens were protected by 2 different tumuli belonging to a set of tumuli and dolmens used or reused for at least $1500 \mathrm{yr}$ during Neolithic period. Same types of Megalithic monuments are also found in Brittany, W France (Mohen, 1973).

\section{Ly-968. Bougon, Tumulus $F, n^{\circ} 3$}

$4470 \pm 230$ 2520 BC

Bones from Tumulus $\mathrm{F}$ probably built during Chassean period but reused afterward; artifacts of "Vienne-Charente" type (Late Neolithic) were id. 
Ly-967. Bougon, Tumulus $F, n^{\circ} 2$

$4790 \pm 220$

2840 BC

dolmen looks like La tumulus as Ly-968. This "Angoumoisian type" first used by a Chasseansaie tumulus, Charente Maritime, but it was Bougon style.

\section{Ly-966. Bougon, Tumulus $\mathrm{E}, \mathrm{n}^{\circ} \mathrm{I}$}

$5800 \pm 230$

$\mathbf{3 8 5 0}$ BC

of "Groupe des Cous" E, older than Tumulus F, including artifacts posing, this monus Type; may be Early Neolithic. Although less imzoch, Finistère, for way be compared to Barnenez Cairn at Ploue$\mathrm{p} 215)$.

General Comment (JPM): 3 dates agree well with archaeologic interpretation of site, Ly-968, a little younger than 967 may indicate reoccupation of site after Chassean period; Ly-966 is 1 of oldest dates obtained for such a monument and may be compared to Gif-165: $5800 \pm 300$ from Le Guegnoc 1 and to Sa-95: $5840 \pm 300$ from Kercado; both sites in W Brittany ( $R, 1966, \mathrm{v} 8, \mathrm{p} 76)$. Ly-967 corresponds to 1st occupation time of funerary room and perhaps to building of monuments.

\section{Ly-864. Perigneux, J XII-XIII, Loire}

$5140 \pm 140$

Charcoal from Layer 4 of a Chassean hearth to $S$ of the Violette near Périgneux, Loire $\left(45^{\circ} 26^{\prime} \mathrm{N}, 4^{\circ} 9^{\prime} \mathrm{E}\right)$. Coll 1965 by J $\mathrm{P}$ Thévenot and subm 1972 by J Combier, Dir Antiquités préhistoriques, Romanèche, Saône et Loire. Comment (JC): similar to S France Chassean and may be a little older than Norman Chassean. Agrees with many other results on Chassean civilization and indicates penetration into Massif Central earlier than supposed (Combier, 1962).

\section{Ly-970. Aubigny au Bac, Nord}

$5570 \pm 250$

Human bones from sepulture assoc with Campaniform industry at Aubigny au Bac, Nord (50 $\left.15^{\prime} \mathrm{N}, 3^{\circ} 9^{\prime} \mathrm{E}\right)$. Coll 1972 and subm 1973 by $\mathrm{P}$ Demolon, Mus Chartreuse, Douai. Comment $(\mathrm{PD})$ : sepulture was dug into ground but covered by a polishing stone and contained a Campaniform vessel (Demolon et al, 1975). Waller's sepulture seems nearly contemporaneous, ca $1800 \mathrm{Bc}$, but date is inexplicably much older, although no trace of 2 occupation periods was found.

\section{Mouligna series, Bidart, Pyrénées Atlantiques}

Peat assoc with charcoal coll at lower and upper part of archaeologic layer with flints and burnt gravels, attributed to Asturian. Neolithic was expected (Oldfield, 1960) at La Mouligna near Bidart, Pyrénées Atlantiques $\left(43^{\circ} 25^{\prime} \mathrm{N}, 1^{\circ} 49^{\prime} \mathrm{W}\right)$. Coll and subm 1973 by $\mathrm{C}$ Chauchat. 


\section{Ly-882. Mouligna $n^{\circ}$ I sommet}

From top of layer.

\section{$5550 \pm 150$}

Ly-883. Mouligna $n^{\circ}$ 2, base

3600 вC

From base of layer.

General Comment (CC): previous date gave a more recent age: Q-314: $5100 \pm 130(\mathrm{R}, 1960, \mathrm{v} 2, \mathrm{p} 70)$, but wood used for dating was not clearly assoc with industry, which might be a little older as confirmed by present results. Stratigraphic inversion is only statistic and average of both results is: Ly-882/883: $5650 \pm 100(3700 \mathrm{BC})$. Attribution of Austrian civilization to Early or Middle Neolithic period is confirmed.

\section{Ly-865. Reichstett, Fosse 43, Bas-Rhin}

$5940 \pm 140$ 3990 BC

Fossil pitch mixed with earth from Grave 43 in loess at Reichstett, Bas-Rhin $\left(48^{\circ} 38^{\prime} \mathrm{N}, 7^{\circ} 45^{\prime} \mathrm{E}\right)$. Coll 1972 and subm 1973 by A Thevenin. Assoc with Neolithic "Rubanné" industry. Comment (AT): date agrees perfectly with expected age, may be compared to Ly-335: $5490 \pm 140$ BP (R, 1973, v 15, p 143) from attributed "Rubanné récent" level at Gondenans les Montby site, Doubs.

\section{Ly-868. Abri Cornille, Couche 6}

$7000 \pm 130$

Charcoal from earth in Layer 6 at L'Abri Cornille near Istres, Bouches du Rhône $\left(43^{\circ} 39^{\prime} \mathrm{N}, 5^{\circ} 0^{\prime} \mathrm{E}\right)$. Coll 1969 and subm 1972 by M Escalon de Fonton, Marseille. Assoc with Montadian industry (Epipaleolithic) and with pollens and sediments attributed to Dryas III. Humic fraction of charcoal was previously measured: Ly-413, $8100 \pm$ 130 вP (R, 1973, v 15, p 527). Comment (MEF): date is obviously too young for this industry and proves that hearth was polluted by overexposure to open air (Escalon de Fonton, 1966).

\section{Ly-863. Les Charmes 65, Sermoyer, Ain}

$8490 \pm 170$

Charred nuts from Layer $7 \mathrm{Y}$ in Mesolithic Sauveterrian site at Les Charmes near Sermoyer, Ain $\left(46^{\circ} 29^{\prime} \mathrm{N}, 4^{\circ} 58^{\prime} \mathrm{E}\right)$. Coll 1965 by J P Thévenot and subm 1972 by J Combier. Comment (JC): in statistical range of Gif-1597: $8150 \pm 190$ вP (R, 1974, v 16, p 37) and perfectly agrees with oldest dates of Tardenoisian industry, eg, at Montbani, Aisne, Gif-356, or at Coincy en Tardenois, Aisne, Gif-1266 (R, 1972, v 14, p 290). Contemporaneous with Sauveterrian layers in Rouffignac site, Dordogne: 3 GrN dates (R, 1972, v 14, p 59) and probably older than Sauveterrian layers in Montclus site, Gard: 4 Ly dates ca 7800 вP (R, 1971, v 13, p 62). 


\section{Paleolithic periods}

Ly-958. La Baume Loire $11 \mathrm{n}^{\circ}$ 2, Haute-Loire

$10,200 \pm 950$ 8250 BC

Bits of charcoal from hearth assoc with flints of Late Upper Paleolithic industry in basaltic Rock Shelter II at La Baume Loire near Solignac, Haute-Loire $\left(44^{\circ} 56^{\prime} \mathrm{N}, 3^{\circ} 54^{\prime} \mathrm{E}\right)$. Coll and subm 1973 by A Cremillieux, Le Monastier sur Gazeille. Comment (AC): despite large statistical range due to scarcity of material, date confirms Upper Paleolithic occupation of site. True age may be older since pollution occurred in site from upper layer, shown by previous date on same layer: Ly-452, $3950 \pm 120$ (R, 1973, v 15, p 147).

\section{Grotte Jean Pierre 2 series, Saint Thibaud de Couz, Savoie}

Samples from the only archaeologic layer of Jean Pierre 2 grotto, Saint Thibaud de Couz, Savoie $\left(45^{\circ} 40^{\prime} \mathrm{N}, 5^{\circ} 50^{\prime} \mathrm{E}\right)$. Coll 1969 and subm 1973 by $\mathrm{P}$ Bintz, Inst Dolomieu, Grenoble.

\section{Ly-925. Os de la grotte Jean-Pierre 2}

$$
\begin{aligned}
& 12,400 \pm 240 \\
& 10,450 \mathrm{BC}
\end{aligned}
$$

Bones.

\section{Ly-926. Charbon de la Grotte Jean-Pierre $2 \quad 11,330$ BC \\ Charcoal.}

General Comment (BP): previous dates on charcoal from same site: Ly-828, 12,470 \pm 200 and Ly-390, 13,300 \pm 280 (R, 1975, v 17, p 25). Disparity of results was ascribed either to pollution or to maximal statistic fluctuation. New results confirm 900-yr range. As archaeologic layer is fairly thick, disparity of ${ }^{14} \mathrm{C}$ dates may only be explained by compaction into 1 layer of several occupations, which can be distinguished in neighboring grotto, Jean-Pierre 1.

\section{Ly-894. Grotte du Crest, Viry, Saône et Loire 10,900 BC}

Bone splinters from little Magdalenian site in Le Crest Grotto near Viry, Saône et Loire $\left(46^{\circ} 27^{\prime} \mathrm{N}, 4^{\circ} 0^{\prime} \mathrm{E}\right)$. Coll 1958 by R Horiot (1965) and subm 1973 by R Desbrosse, Blanzy. Comment (RD): approaching Ly-393: 12,500 \pm 240 BP from Magdalenian Layer of Solutré site, typology being comparable (Combier, 1955). Date should correspond to Bölling period but microfauna indicate very cold, steppe-like climate (Combier, 1959). However ${ }^{14} \mathrm{C}$ dates of climatic phases of the Late Würm, before Alleröd, in Middle East France are neither well established (Evin, 1974) nor very numerous (Desbrosse and Girard, 1974).

\section{Gare de Couze series, Lalinde, Dordogne}

Bones from 2 layers of Magdalenian site La Gare de Couze near Lalinde, Dordogne $\left(44^{\circ} 49^{\prime} \mathrm{N}, 0^{\circ} 44^{\prime} \mathrm{E}\right)$. Coll 1957 by $\mathrm{F}$ Borde and subm 1974 by F Delpech, Lab Géol Quaternaire, Univ Bordeaux I. Industries 
assoc with bones of antelope Saïga whose existence in SE France seems short-lived and localized (Fitte \& Sonneville Borde, 1962).

\section{Ly-976. La gare de Couze, Couche $\mathrm{C}$}

$11,750 \pm 310$

Assoc Industry: Magdalenian VI. Expected age: 10,000 вс.

\section{Ly-975. La gare de Couze, Couche H}

$12,430 \pm 320$

Assoc limited industry: Magdalenian V or VI, similar age expected. General Comment (FD): both values are in stratigraphic order and in general date range for Magdalenian $\mathrm{V}$ or $\mathrm{VI}$; see La Madeleine and Duruthy sites below. Ly-391: 10,900 \pm 230 вр (R, 1970, v 12, p 554) comes from an upper layer assoc with Magdalenian industry.

\section{La Madeleine series, Tursac, Dordogne}

Samples from several layers in La Madeleine site at Tursac, Dordogne $\left(44^{\circ} 58^{\prime} \mathrm{N}, 1^{\circ} 02^{\prime} \mathrm{E}\right)$. Coll 1970-71 and subm 1973 (except Ly-234) by J M Bouvier, Lab Géol Quaternaire, Univ Bordeaux I (Bouvier, 1973).

Ly-919. La Madeleine $n^{\circ} 19$

$12,640 \pm 260$ $10,690 \mathrm{BC}$

$\delta^{13} \mathrm{C}=-19.2 \%$

Bones from Layer F, Level 7. Assoc with industry from beginning of Magdalenian VI.

\section{Ly-920. La Madeleine $n^{\circ} 21$}

$$
\begin{aligned}
& 12,750 \pm 240 \\
& 10,800 \mathrm{BC} \\
& \delta^{13} \mathrm{C}=-19.3 \%
\end{aligned}
$$

Bones from Layer G, Level 9. Assoc with industry from end of Magdalenian V.

\section{Ly-921. La Madeleine $n^{\circ} 25$}

$$
\begin{aligned}
& 13,070 \pm 190 \\
& 11,120 \text { BC }
\end{aligned}
$$

$$
\delta^{13} \mathrm{C}=-19.5 \%
$$

Bones from Layer I, Level 13. Assoc with industry from beginning of Magdalenian V.

\section{Ly-922. La Madeleine $n^{\circ} 26$}

$13,440 \pm 300$

\section{$11,490 \mathrm{BC}$}

$\delta^{13} C=-20.1 \%$

Bones from Layer J, Level 14. Assoc with industry from end of Magdalenian IV.

\section{Ly-234. La Madeleine $n^{\circ} 20$ to 24 and 10}

$$
\begin{aligned}
& \text { Modern } \\
& \delta^{14} \mathrm{C}=+\mathbf{0 . 7 \%} \% \\
& \pm \mathbf{2 . 4}
\end{aligned}
$$

2 bits of charcoal from 2 places in Level 9. Assoc with Late Magdalenian V. Coll and subm 1968. Comment: $\delta^{14} \mathrm{C}$ value suggests 1 charcoal piece is old and the other is very modern. Result indicates difficulty of 
dating small samples and importance of removing spurious material. General Comment (JMB): La Madeleine is the eponymous site of Magdalenian civilization, with 19 levels embedding industry from Stages IVVI of Magdalenian tradition. The 1st dates are of passages between IV to $\mathrm{V}$, and $\mathrm{V}$ to VI stages, which are in stratigraphic succession and suggest a short Magdalenian V stage and long VI stage. Other dates will be necessary for Stage IV. Results are comparable to those for Magdalenian industry at Duruthy site, Landes (see below), with identical dates for end of Magdalenian IV.

\section{Duruthy series, Sorde-L'Abbaye, Landes}

Bones from several layers in Duruthy grotto near Sorde-L'Abbaye, Landes, $\left(43^{\circ} 31^{\prime} \mathrm{N}, 1^{\circ} 10^{\prime} \mathrm{W}\right)$. Coll 1972 and subm 1973 by R Arambourou, Inst Quaternaire, Univ Bordeaux I.

Ly-858. Duruthy, Couche 3, sommet

$11,150 \pm 220$

From top of layer including Magdalenian VI industry.

Ly-859. Duruthy, Couche 4, sommet

9200 BC

From top of layer including Magdalenian IV industry.

\section{Ly-860. Duruthy, Couche 4, base}

$13,510 \pm 220$

$11,560 \mathrm{BC}$

From base of layer including Magdalenian IV.

$13,840 \pm 210$

$11,890 \mathrm{BC}$

\section{Ly-861. Duruthy, Couche 5}

$14,180 \pm 200$

$12,230 \mathrm{BC}$

From several levels in upper part of layer including Magdalenian III. General Comment (RA): dates are in expected range and compare to La Madeleine results (see above). With no date from lowest layer of Magdalenian VI, estimated length of industry, probably long is impossible, Magdalenian IV duration may be longer than dates show due to possible erosion of lowest part of layer, as evident in upper part of Magdalenian III layer. Thermoluminescence dates were made on samples from Layers 3 and 4 by Lab Cristallographie et Physique du Cristal, Univ Bordeaux I (Schvoerer et al, 1974) with the following results: BOR-6: 11,290 BP for Layer 3 (Ly-858), and BOR-7: 14,500 вP for Layer 4 (Ly-859-860) with ca $10 \%$ range. Both dating methods correspond.

\section{Ly-977. Fongaban, Couche III, Saint-Emilien, $\quad 14,300 \pm 680$ Gironde \\ 12,350 вС}

Bones from Layer III in Le Vallon de Fongaban site, at Bergat near Saint-Emilion Gironde $\left(44^{\circ} 53^{\prime} \mathrm{N}, 0^{\circ} 10^{\prime} \mathrm{W}\right)$. Coll 1970 by J P Rigaud and subm 1974 by $F$ Delpech. Assoc with industry typologically attributed to Late Magdalenian and with mainly bisons, and also horses and saïgas. Presumed from Würm IV with expected age ca 12,000 BP (Rigaud et al, 1970). Comment (JPR): date is older than expected for Magda- 
lenian IV even accounting for large statistical range. Either pollution occurred or artifact used for archaeologic attribution appeared earlier than supposed.

\section{Le Flageolet II series, Bezenac, Dordogne}

Bones from several layers in Le Flageolet II rock shelter $\left(44^{\circ} 49^{\prime} \mathrm{N}\right.$, $\left.1^{\circ} 6^{\prime} \mathrm{E}\right)$. Coll 1971 and subm 1973 by J P Rigaud, Inst Quaternaire, Bordeaux I.

\section{Ly-916. Le Flageolet $11, n^{\circ} 1$}

\section{Ly-917. Le Flageolet $11, n^{\circ} 2$}

\section{Ly-918. Le Flageolet $11, n^{\circ} 3$}

$12,870 \pm 390$ 10,920 BC $\delta^{13} \mathrm{C}=-19.5 \%$

$14,110 \pm 690$ $12,160 \mathrm{BC}$ $\delta^{13} C=-20.5 \%$ o

$15,250 \pm 320$ $13,300 \mathrm{BC}$ $\delta^{13} \mathrm{C}=-18.8 \%$

General Comment (JPR): assoc industry attributed to Late Magdalenian period, based on typologic character (Rigaud, 1970). Ly-916 is in range of usual dates for period, but Ly-917 and especially 918 are out of range. Either dates are too old for unknown reason, or special type of industry appeared earlier than supposed.

\section{Ly-978. Combe-Cullier, Lacave, Lot}

$15,030 \pm 330$ $13,080 \mathrm{BC}$

Bones from Layer IX in Combe Cullier site near Lacave, Lot $\left(44^{\circ}\right.$ $\left.50^{\prime} \mathrm{N}, 1^{\circ} 34^{\prime} \mathrm{E}\right)$. Coll 1971 by $\mathrm{J} F$ Flies and subm 1974 by $\mathrm{F}$ Delpech. Assoc with Magdalenian industry and with reindeers, chamois, and saiga (Lorblanchet, 1969). Comment (FD): date indicates time of E-ward extension of antelope saïga. Comparable to Magdalenian III layer of Saint-Eulalie grotto at Espagnac, Lot, previously dated: Gif-2194, 15,200 \pm 300 вр (R, 1974, v 16, р 26).

\section{Laugerie Hautes series, Les Eyzies, Dordogne}

Bones from several Magdalenian layers in Laugerie-Haute site near Les Eyzies, Dordogne (44 $\left.58^{\prime} \mathrm{N}, 0^{\circ} 57^{\prime} \mathrm{E}\right)$. Coll 1958 by F Bordes (1958) and subm 1974 by $F$ Delpech. As in other sites, industry embedded in layers assoc with bones of antelope saïga.

\section{Ly-974. Laugerie Haute Est, Magdalenian}

Bones from several layers in main geologic secs assoc with Magdalenian III industry. Presumed climatic phase: Würm IV.

\section{Ly-973. Laugerie Haute Est, Magdalénian II $\quad 17,040 \pm 440$}

Bones from several layers not stratigraphically joining main geologic secs assoc with Magdalenian II industry. 
$18,260 \pm 360$

\title{
Ly-972. Laugerie-Haute Est, Magdalénian 0
}

$16,310 \mathrm{BC}$

Bones from 2 layers in main geologic sec assoc with Magdalenian 0 industry and presumably beginning of Würm IV.

General Comment (FB \& FD): Ly-974 and -972 agree with expected age and, in general, possible date range for Magdalenian III and 0 industries. But Ly-973 seems too near -972, because of presence of Magdalenian I layer between these layers. This connection between dated bones and Magdalenian II industry seems doubtful or a large statistical fluctuation of at least $2 \sigma$ must be supposed between true ${ }^{14} \mathrm{C}$ age and obtained value.

\section{La Salpétrière series}

Bones from 10 layers in 4 geol secs in La Salpétrière site near Remoulins Gard (43 $\left.55^{\prime} \mathrm{N}, 4^{\circ} 35^{\prime} \mathrm{E}\right)$. Coll 1964 and subm 1973 by $\mathrm{M}$ Escalon de Fonton. The 4 secs were excavation sectors left intact by numerous archaeologists and correlations between secs were made with the industries found. Site shows longest stratigraphy in SE France (Escalon de Fonton, 1965). All bones contained normal collagen (ca 2\%) except oldest $.3 \%$.

\section{Ly-937. La Salpétrière, Grand Témoin Bayol, Couche 6}

$10,680 \pm 300$ 8730 BC

Assoc industry: Upper Salpétrian (Magdalenien V). Expected age: са 13,000 вр.

\section{Ly-938. La Salpétrière, Grand Témoin} Bayol, Couche 7-14

$11,080 \pm 250$ 9050 BC

Assoc industry: Middle Salpétrian (Middle Magdalenian). Expected age: ca $14,000 \mathrm{BP}$.

\section{Ly-939. La Salpétrière, Centre du $\quad 18,880 \pm 300$ Porche, Couche $6 \quad 16,930$ BC}

Assoc industry: Middle Salpétrian (Middle Magdalenian). Expected age: ca $14,000 \mathrm{BP}$.
Ly-940. La Salpétrière, Grand Témoin $\quad 20,200 \pm 660$
18,250 вC Bayol, Couche 24

Assoc industry: Middle Solutréan. Expected age: ca 20,000 вP.

\section{Ly-941. La Salpétrière, Petit Témoin} Bayol, Couche $V_{2}$

Assoc industry: Early Solutréan. Expected age: ca 21,000 BP.

\author{
$20,630 \pm 770$ \\ Ly-942. La Salpétrière, Centre, Couche $30 \mathrm{~A} \quad 18,680 \mathrm{BC}$ \\ Assoc industry: Late Aurignacian. Expected age: 22,000 BP.
}


Ly-943. La Salpétrière, Centre, Couche 30 E

Assoc industry: Late Middle Aurignacian. Expected age: 23,000 вр.

4000

$27,530 \pm 2600$

Ly-944. La Salpétrière, Centre, Couche 30 M 25,580 BC

Very little organic matter available. Assoc industry: Middle Aurignacian. Expected age: 23,000 BP.

Ly-945. La Salpétrière, Centre, Couche 30-0

$20,860 \pm 460$

Assoc industry: Gravettian. Expected age: 24,500 BP. 18,910 BC

Ly-946. La Salpétrière, Centre, Couche $32 \mathrm{C}$

$21,380 \pm 760$

Assoc industry: Early Aurignacian. Expected age: ca 31,000 вр.

General Comment (ME de F): all dates from Salpétrian layers do not agree with expected ages and are either younger (Ly-937-938) or older (Ly-939). Likewise, Early Solutrean date should be ca 20,000 вP, according to layer correlations. Such a value (Ly-940) is normal for Middle Solutrean: see eg, Oullins grotto, Ardèche, Ly-799: 19,710 \pm 400 вP (R, 1975, v 17, p 28). The 3 dates ca 21,000 вP for Late and Middle Aurignacian are 1st results for this inclustry, correlated with Perigordian IV to VI stages in the Dordogne (Laville, 1975) with ${ }^{14} \mathrm{C}$ dates ca 23,000 BP. Inversion of values between Ly-944 and -946 with respect to industries remains unexplained but is confirmed by organic matter. La Salpétrière site yields unsatisfactory dates despite good bony material.

\section{Ly-981. Grotte de Conives, Thonay, Indre}

$32,000 \pm 900$

Bones from Conives grotto near Thonay, Indre $\left(46^{\circ} 37^{\prime} \mathrm{N}, 1^{\circ} 29^{\prime} \mathrm{E}\right)$. Coll and subm 1974 by J Allain, Antiquitées préhistoriques, Bourges. Bones are not assoc with industry in site but human settlements occurred in rock shelters nearby. Site was hyenas' den with Megaceros bone, supposedly contemporary with neighboring human habitats. Comment (JA): date indicates period corresponding to Middle Paleolithic industries, whereas industries from human habitats are Magdalenian; thus neighboring human and animal remains are not contemporaneous.

\section{La Grande Roche series, Quincay, Vienne}

Carbonaceous earth from layer, "black ensemble", Sample no $4 \mathrm{~L}(\mathrm{I})$ 22 En, in Châtelperronian site La Grande Roche, near Quincay, Vienne $\left(46^{\circ} 36^{\prime} \mathrm{N}, 0^{\circ} 15^{\prime} \mathrm{E}\right)$. Coll 1970 and subm 1973 by $\mathrm{F}$ Levêque, Dir Antiquités préhist, Poitiers.
Ly-790.
Quincay
4L (I) 22 En Reliquat
$11,910 \pm 200$
9960 BC 
Ly-791. Quincay 4L (I) 22 En Extra

18,350 вс

General Comment (FL): humic fraction date is older than insoluble fraction, but both values do not fit with age of Châtelperronian industry (beginning of Upper Paleolithic) eg, in Le Renne grotto at Arcy sur Cure, Yonne, GrN-1742: 33,860 \pm BP (R, 1963, v 5, p 116). Probably earth samples contained numerous thin rootlets that pretreatment did not eliminate. Other measurements on samples from same layer will be made later.

\section{Gigny sur Suran series, Jura}

Bones from 3 layers in La Balme grotto site near Gigny sur Sura,

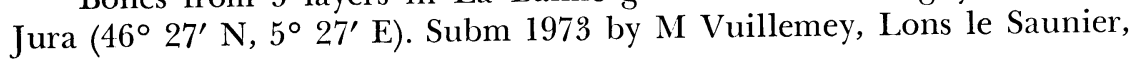
Jura.

\section{Ly-789. Gigny sur Suran, Niveau VIII, $n^{\circ} 2 \quad 26,550$ BC}

$28,500 \pm 1400$

From same layer as Ly-566: 29,500 \pm 1400 (R, 1973, v 15, p 521). Coll 1970. Comment (MV): date confirms previous measurement (average: Ly-566/789: 28,900 $\left.\pm \begin{array}{r}1200 \\ 800\end{array}\right)$ showing that Middle Paleolithic industries may have lasted longer in Jura region when Early Aurignacian or Perigordian industries appeared in other regions. Bird fauna indicate a cold climate (Mourer-Chauviré, 1975).

Ly-971. Gigny sur Suran, Niveau XV, no 1

Assoc with typical Mousterian "enriched in denticules". Coll 1972.

\section{Ly-804. Gigny sur Suran, Niveau XX, no 2}

Assoc with typical Mousterian "rich in racloirs". Coll 1971.

General Comment (MB): small amount of organic matter in bones reduces dating limit and only Ly-789 gives a finite date marking end of Mousterian occupation. The other dates are only minimum. Other measurements on larger samples will be made later.

\section{HYDROGEOLOGIC SAMPLES}

\section{Ly-818. Eau de Tinogasta, Argentina \\ $88.2 \pm 1.5 \%$ modern $\delta^{13} C=-11.31 \pm 0.04 \%$ \%}

Water from aquifer system near Tinogasta, Argentina $\left(28^{\circ} 0^{\prime} \mathrm{S}, 67^{\circ}\right.$ $\left.40^{\prime} \mathrm{W}\right)$. Coll and subm 1973 by J Molinari, Centre d'Etudes Nucléaires Grenoble. Treatment on sampling place was made according to process recommendations of IAEA, Vienna.

\section{Eau de la Mine de Razès series, Haute-Vienne}

Samples from 2 layers in Rezès uranium mine, Haute-Vienne $\left(46^{\circ}\right.$ $2^{\prime} \mathrm{N}, 1^{\circ} 20^{\prime} \mathrm{E}$ ). Coll 1971 by Centre d'Energie Atomique and subm 1971 by Y Vuillaume, Bur recherches Geol Min, Orléans. Mine is dug in gneiss and slightly mineralized water from layer percolates probably 
vertically from surface. No treatment was made on ground and $\mathrm{CO}_{2}$ used for counting was directly evolved by $\mathrm{HCl}$ in lab.

\section{Ly-516. Razès galerie profonde}

From $-225 \mathrm{~m}$.

\section{Ly-517. Razès, galerie branche nord}

From $-180 \mathrm{~m}$.

\section{Ly-518. Razès, galeries branche sud}

From $-180 \mathrm{~m}$.

General Comment: contrary to presumed values, ${ }^{14} \mathrm{C}$ contents show that percolating water in mine layers is fairly old, especially at $-225 \mathrm{~m}$, suggesting a large aquifer in gneiss.

\section{Aïn Beni Mathar series, Morocco}

Water from several wells in Aïn Beni Mathar aquifer basin, S Oujda, E Morocco. Coll by M Dupuy, Dir Hydrogeol Maroc, and subm 1972 by Y Vuillaume. Ground water is in an aquifer of fractured dolomitic calcareous rocks, with large flows to springs or artesian wells. The isotopic study was made to choose between several hypotheses for water origin and to detect an eventual exhaustion of the water reserves.

\begin{tabular}{lclrrr}
\hline \multicolumn{1}{c}{ Sample } & Loc & N Lat & W Long & \multicolumn{1}{c}{$\begin{array}{c}\delta^{13} \mathrm{C} \% \\
\pm 0.05\end{array}$} & \multicolumn{1}{c}{$\begin{array}{c}{ }^{14} \mathrm{C} \% \\
\text { modern }\end{array}$} \\
\hline Ly-634. Janvier & $23-25$ & $33^{\circ} 44^{\prime}$ & $2^{\circ} 20^{\prime}$ & -13.13 & $8.7 \pm 0.9$ \\
Ly-635. Février & $27-18 \mathrm{~B}$ & $34^{\circ} 0^{\prime}$ & $2^{\circ} 1^{\prime}$ & -12.80 & $28.5 \pm 0.8$ \\
Ly-636. Mars 2 & $54-18$ & $34^{\circ} 0^{\prime}$ & $2^{\circ} 1^{\prime}$ & -11.18 & $6.0 \pm 0.7$ \\
Ly-637. Avril & $55-18$ & $34^{\circ} 5^{\prime}$ & $2^{\circ} 13^{\prime}$ & -12.54 & $4.9 \pm 0.6$ \\
Ly-638. Mai & $24-25$ & $33^{\circ} 47^{\prime}$ & $1^{\circ} 54^{\prime}$ & -11.48 & $3.4 \pm 0.6$ \\
Ly-639. Juin & $25-25$ & $33^{\circ} 21^{\prime}$ & $2^{\circ} 16^{\prime}$ & -15.69 & $47.7 \pm 0.9$ \\
Ly-640. Juillet & $61-18$ & $34^{\circ} 7^{\prime}$ & $2^{\circ} 8^{\prime}$ & -12.73 & $2.8 \pm 1.7$ \\
Ly-641. Août & $5-25$ & $33^{\circ} 18^{\prime}$ & $2^{\circ} 0^{\prime}$ & -13.65 & $8.5 \pm 0.7$ \\
Ly-642. Septembre & $68-18$ & $34^{\circ} 2^{\prime}$ & $2^{\circ} 4^{\prime}$ & -12.61 & $6.0 \pm 0.6$ \\
Ly-643. Octobre & $59-18$ & $34^{\circ} 7^{\prime}$ & $2^{\circ} 7^{\prime}$ & -13.01 & $12.2 \pm 0.7$ \\
Ly-644. Novembre & $55-18$ & $34^{\circ} 5^{\prime}$ & $2^{\circ} 13^{\prime}$ & -7.03 & $3.5 \pm 0.7$ \\
Ly-645. Décembre & $61-18$ & $34^{\circ} 7^{\prime}$ & $2^{\circ} 8^{\prime}$ & -5.77 & $3.2 \pm 0.4$ \\
\hline
\end{tabular}

General Comment $(\mathrm{YV}): \delta^{13} \mathrm{C}$ values show no isotopic exchange between aquifer and water. High ${ }^{14} \mathrm{C}$ content assoc with ${ }^{3} \mathrm{H}$ measurable content suggest a recent water drift in sampling points $27 / 18 \mathrm{~B}$ and $25 / 25$. All radiocarbon values and other isotopic results $\left({ }^{13} \mathrm{C},{ }^{18} \mathrm{O}\right.$, and $\left.{ }^{3} \mathrm{H}\right)$ indicate a double supply for aquifer: one is autochtonal at outcropping of aquifer formation, the other is allauchtonal for all ground water and comes from 
High and Middle Atlas Mts. Values also confirm that flow depends on deep structure of geol beds and especially on their discontinuity (Vuillaume, 1972).

\section{Miocene limestone of Cyrenaic series, Libya}

Water from an aquifer system in Karstic Miocene limestone of Cyremaic, N Lybia. Coll during a program of studies (GEFLI) and subm by Bur Recherches Géol Min, Orléans. Most ground water is confined with natural outlets along Mediterranean sea coast (Castany et al, 1974).

\begin{tabular}{|c|c|c|c|c|c|}
\hline Sample & Date & N Lat & E Long & $\begin{array}{l}\delta^{13} \mathrm{C} \% \text { \% } \\
\pm 0.05\end{array}$ & $\begin{array}{l}{ }^{14} \mathrm{C} \% \\
\text { modern }\end{array}$ \\
\hline Ly-568. Salantah & $12 / 7 / 71$ & $32^{\circ} 34^{\prime}$ & $21^{\circ} 38^{\prime}$ & -6.97 & $35.5 \pm 1.0$ \\
\hline Ly-569. Fitayah $\mathrm{N}^{\circ} 7$ & & $32^{\circ} 43^{\prime}$ & & & $2.5 \pm 0.6$ \\
\hline Ly-570. Fitaya & & $32^{\circ} 46^{\prime}$ & $22^{\circ} 40^{\prime}$ & -6.90 & $18.7 \pm 0.7$ \\
\hline Ly-571. Al Abyar $\mathrm{N}^{\circ} 2$ & $12 / 17 / 72$ & $32^{\circ} 13^{\prime}$ & $20^{\circ} 34^{\prime}$ & -5.92 & $4.0 \pm 0.6$ \\
\hline Ly-572. Al Haniyah & & $50^{\prime}$ & $21^{\circ} 26^{\prime}$ & -9.04 & $62.2 \pm 1.0$ \\
\hline Ly-573. Marawah & 1 & $33^{\prime}$ & $21^{\circ} 20^{\prime}$ & -6.79 & $9.7 \pm 0.7$ \\
\hline Ly-574. Miltani & $1 / 22$ & $17^{\prime}$ & $\circ 42^{\prime}$ & -0.99 & $4.6 \pm 0.9$ \\
\hline Ly-575. Sadi Rahumah & & & $20^{\circ} 52^{\prime}$ & -0.36 & $37.8 \pm 0.8$ \\
\hline Ly-576. GEFLI C9 & $1 / 2$ & & $20^{\circ} 32^{\prime}$ & -6.05 & $11.9 \pm 0.7$ \\
\hline Ly-601. Barradah & $3 / 29 /$ & $2^{\circ} 53^{\prime}$ & $22^{\circ} 0^{\prime}$ & & $94.3 \pm 1.5$ \\
\hline Ly-602. GEFLI C13 & $3 / 24 /$ & $\circ 38^{\prime}$ & $20^{\circ} 16^{\prime}$ & -0.92 & $\leqslant 2.3$ \\
\hline Ly-603. Al Labraq & 3 & & $20^{\circ} 50^{\prime}$ & -12.49 & $112.3 \pm 1.5$ \\
\hline Ly-604. Blue Lagoon & & $12^{\prime}$ & $20^{\circ} 8^{\prime}$ & -8.25 & $38.6 \pm 2.1$ \\
\hline Ly-605. Dabuffiyah & & $2^{\circ} 47^{\prime}$ & $22^{\circ} 6^{\prime}$ & -9.68 & $62.2 \pm 1.2$ \\
\hline Ly-606. Baninal & $2 / 12 /$ & $32^{\circ} 7^{\prime}$ & $20^{\circ} 16^{\prime}$ & -7 & $17.4 \pm 0.6$ \\
\hline Ly-607. GEF & $2 / 13 / 7$ & $1^{\circ} 43^{\prime}$ & $20^{\circ} 15^{\prime}$ & -3.06 & $5.1 \pm 2.0$ \\
\hline Ly-608. Darnah S2 & $4 / 1 / 72$ & $42^{\prime}$ & $22^{\circ} 30^{\prime}$ & -7.32 & $61.2 \pm 2.1$ \\
\hline Ly-609. GEFLI C7 & & $31^{\circ} 43^{\prime}$ & $20^{\circ} 13^{\prime}$ & -1.55 & $12.6 \pm 0.8$ \\
\hline Ly-629. Al Marj $N^{\circ} 10$ & $8 / 14 / 72$ & $32^{\circ} 27^{\prime}$ & $20^{\circ} 46^{\prime}$ & -8.06 & $43.2 \pm 1.1$ \\
\hline Ly-665. GEFLI C1 & $6 / 26 / 72$ & $32^{\circ} 10^{\prime}$ & $20^{\circ} 20^{\prime}$ & -4.24 & $12.0 \pm 0.6$ \\
\hline Ly-666. GEFLI C2 & $6 / 25 / 72$ & $32^{\circ} 20^{\prime}$ & $20^{\circ} 46^{\prime}$ & -4.20 & $4.6 \pm 0.6$ \\
\hline Ly-667. GEFLI C3 & & $32^{\circ} 23^{\prime}$ & $20^{\circ} 22^{\prime}$ & -5.06 & $21.4 \pm 0.6$ \\
\hline Ly-668. GEFLI C5 & $7 / 31 / 72$ & $32^{\circ} 16^{\prime}$ & $20^{\circ} 22^{\prime}$ & -4.53 & $26.6 \pm 0.7$ \\
\hline Ly-669. GEFLI C10 & $7 / 1 / 72$ & $32^{\circ} 47^{\prime}$ & & -1.90 & $3.3 \pm 0$ \\
\hline Ly-670. GEFLI Ci 14 & $6 / 25 / 72$ & $32^{\circ} 41^{\prime}$ & $22^{\circ} 36^{\prime}$ & -3.81 & $27.6 \pm 0.8$ \\
\hline
\end{tabular}

General Comment: assoc with ${ }^{3} \mathrm{H}$, low values of ${ }^{14} \mathrm{C}$ content indicate mixing between recent and old waters. Some very low values of ${ }^{14} \mathrm{C}$ content assoc with $\delta^{13} \mathrm{C}$ near $0 \%$ P D B also suggest an isotopic exchange between calcareous aquifer and water. The geographic distribution of radiocarbon data translates general trend of water flow in aquifer: ${ }^{14} \mathrm{C}$ values toward $\mathrm{NE}$ and low value for confined ground water, especially in $\mathrm{SW}$ region. 


\section{Ly-271. Forage de Pernes les Fontaine, Vaucluse}

$3.5 \pm 0.5 \%$ modern $\delta^{13} \mathrm{C}=-3.32 \pm 0.04 \%$

Water from very deep ground water coll by boring near Pernes les Fontaines, Vaucluse $\left(43^{\circ} 59^{\prime} \mathrm{N}, 5^{\circ} 3^{\prime} \mathrm{E}\right)$. Coll 1969 by A Boudin, and subm 1970 by H Paloc, Bur Recherches Géol Min, Montpellier. Sample fully treated in lab. Comment: water is presumed fossil but low ${ }^{14} \mathrm{C}$ activity and presence of some tritium units indicate pollution by surface water possibly via tubing, despite artesian character of ground water at site.

\section{REFERENCES}

Ambert, P, Evin, J, and Gabert, P, 1974, Datation ${ }^{14} \mathrm{C}$ d'un horizon lithochrome würmien en Base Provence Occidentale: Acad sci [Paris] Comptes rendus, ser D,
v 274, p 3531-3534.

Archambault, M, 1968, Recensement provisoire des arbres et formations forestières fossiles du bassin de la moyenne Durance alpestre (Hautes-Alpes): Acad sci [Paris] Comptes rendus, ser D, v 267, p 2101-2104, 2284-2287.

Aubert, D, 1970, Les graviers du mammouth de Praz Rodet (Vallée de Joux, Jura Vaudois): Soc Vaud Sci Nat Bull, v 70, no. 334, p 430-431.

Bordes, F, 1958, Nouvelles fouilles à Laugerie-Haute: L'Anthropologie, v 62, p 205-244. Bottema, S, 1974, Late Quaternary vegetation history of Western Greece: Thesis,
Groningen Univ, 190 p.

Bourdier, F, 1961, Le Basin du Rhône au Quaternaire: Thesis, Univ Paris, 364 p.

Bouvier, J M, 1973, Nouvelle diagnose stratigraphique du gisement éponyme de la Madeleine, Tursac, Dordogne: Acad sci [Paris] Comptes rendus, ser D, v 277,
p 2625-2668.

Castany, G et al, 1974, Etude par les isotopes du milieu du régime des eaux souterraines dans les aquifères de grandes dimensions: I A E A symposium on isotopes in hydrology, Vienna, SM-182/26, p 243-258.

Chapotat, G, 1971, La hache à ailerons médians de Grigny, Rhône: Rev Archćol Est et Centre-Est, v 22, no. 1-2, p 91-96.

Combier, J, 1955, Solutré: Les fouilles de 1907 à 1925. Mise au point stratigraphique et typologique: Travaux Lab Géol, Fac Sci Lyon, Nlle ser, no. 2, p 93-220. 1959, Viry, Informations archéologiques: Gallia-Préhistoire, v 2, p 122-123. 1962, Information Archéologique de la Circonscription de Lyon: Gallia Préhistoire, v 5, p 237-242.

Del Prete, M and Gerricchio, A, 1974, I depositi dei laghi di frana nel quadro dei fenemeni morfegenetici recenti della Val di Sangro: Geol Appl e Idrogeol, Bari.

Delibrias, G, Guillier, M T, and Labeyrie, J, 1964, Saclay natural radiocarbon measurements I: Radiocarbon, v 6, p 233-250.

1966, Gif natural radiocarbon measurements II: Radiocarbon, v 8, p 74-95. 443. $213-254$.

1970, Gif natural radiocarbon measurements V: Radiocarbon, v 12, p 412$280-320$ p $15-94$.

Demolon, P, Felix, R, and Hurtelle, J, 1975, Une sépulture campaniforme à Aubigny au Bac Nord: Soc Française Préhist, v 72, in press. Desbrosse, R and Girard, M, 1974, Azilien et Magdalénien des Douattes (Haute-Savoie):
l'Anthropologie, v 78, p 481-498.

Donze, P, Evin J, Méon-Vilain, H, and Samuel, E, 1971, Sur la présence de formation à lignites, sous-jacentes à la moraine vürmienne, dans la vallée du Rhône, au Nord de Seyssel, Ain: Soc Géol France Bull, v 13, no. 3-4, p 292-297. 
Elouard, P, 1968, Le Nouakchottien, étage du Quaternaire de Mauritanie: Annales Fac Sci Dakar, v 22, p 121-137.

Elouard, P, Faure, H, and Michel, P, 1966, Nouveaux âges absolus ${ }^{14} \mathrm{C}$ en Afrique de l'Ouest: Bull liaison Assoc Sénégal étude Quaternaire de l'Ouest africain, v 12, p 17.

Escalon de Fonton, M, 1965, Recherches sur la préhistoire dans le midi de la France: cahiers Ligures Préhist et Archéol, v 14, pt 3, 7 p.

1966, Du paléolithique sup au Mésolithique dans le Midi Méditerranéen: Soc Préhist Française Bull, v 63, no. 1, p 66-180.

Evin, J, 1974, Essai de Chronologie ${ }^{14} \mathrm{C}$ des principales phases climatiques entre 10,000 et 15,000 BP en France: Soc Languedocienne Géog Bull, v 8, no. 3-4, p 211-220.

Evin, J, Longin, R, Marien, G, and Pachiaudi, C, 1971, Lyon natural radiocarbon measurements II: Radiocarbon, v 13, p 52-73.

Evin, J, Marien, G, and Pachiaudi, C, 1973, Lyon natural radiocarbon measurements III: Radiocarbon, v 15, p 134-155.

- 1973, Lyon natural radiocarbon measurements IV: Radiocarbon, v 15, p 514-533.

1975, Lyon natural radiocarbon measurements V: Radiocarbon, v 17, p 4-34.

Fitte, $\mathrm{P}$ and de Sonneville-Bordes, D, 1962, Le Magdalénien VI de la Gare de Couze Commune de Lalinde, Dordogne: L’Anthropologie, v 66, p 217-246.

Gilot, E, 1970, Louvain natural radiocarbon measurements IX: Radiocarbon, v 12, p 553-558.

Godwin, H and Willis, E H, 1960, Cambridge University natural radiocarbon measurements II: Radiocarbon, v 2, p 62-72.

Cuerricchio, A and Melidoro, G, 1975, Ricerale di geologia applicata all "Archeologia della citta di Sibari: Géol Appl e Idrogeol, v 10, in press.

Guerin, C, 1970, Gisement pléistocène de Jaurens, commune de Nespouls Corrèze, fouille 1970: Soc Sci Hist Archéol Corrèze Bull, v 92, p 17-21.

Guerin, C and Philippe, M, 1971, Les gisements de vertébrés pléistocène du Causse de Martel: Soc Sci et Archèol Corrèze Bull, v 93, p 10-14.

Horiot, R, 1965, Les "alènes" de Viry: Soc Française Préhist Bull, v 62, no. 6, p $199-206$.

Laville, H, 1975, Précisions sur la chronologie du Quaternaire récent: Soc Française Préhist Bull, v 72, no. 1, 15-17.

Laville, H, Pierre-Marie, R P, and Prat, F, 1972, La caverne à Ours du Plo del May, Commune de Verdalle, Tarn: Féd Tarnaise Spéléo-Archéol, Trauvaux et recherches, v 9, p 37-53.

Lemasson, A, 1912, Histoire du royal monastère de Saint-Jacut: Soc Archéol côtes Nord Bull, v 50 .

Lerman, J C, Carbon 14 dating: origin and correction of isotope fractionation errors in terrestrial living-matter: 8th internatl conf on ${ }^{14} \mathrm{C}$ dating, Lower Hutt, Wellington, Oct 1972, v 2, p H17-H28.

Lorblanchet, M, 1969, Aperçu sur le Magdalénien moyen et supérieur du Haut Quercy Cong Préhistorique France, 19th sess, Auvergne 1969, p 256-283.

Mohen, J P, 1973, Tumulus de Bougon, Nécropole néolithique: Soc Hist et Sci DeuxSèvres Bull, ser 42, v 6, no. 2-3, p 1-54.

Mourer-Chauviré, C, 1975, Les oiseaux du Pléistocène moyen et supérieur de France: Doc Lab Géol, Fac Sci Lyon, no. 64, 604 p.

Oldfield, F, 1960, The coastal mud-bed at Mouligna, Bidart, and the age of the Asturian industry in the Pays Basque: Pollen et Spores, v 2, p 57-70.

Philibert, $M$ and Moser, F, 1974, l'abrinéolithique des Champs-Vieux à Solignac sur Loire, Haute-Loire: premiers résultats: Cong Préhistorique France, 20ih sess, Martigues, in press.

Reille, M, 1975, Contribution Pollenanalytique à l'histoire Tardiglaciaire et Holocène de la végétation de la montagne Corse: Thesis, Aix Marseille, $206 \mathrm{p}$.

Rigaud, J P, 1970, Etude préliminaire des industries magdaléniennes du Flageolet II Commune de Bezenac, Dordogne: Soc Française Préhist Bull, v 67, p 456-474.

Rigaud, J P, Lenoir, M, and Delpech, F, 1970, Fouille de sauvetage dans le gisement magdalénien de Fongaban, commune de Saint-Emilion, Gironde; L'anthropologie, v 76, p 595-629. 
Schvoerer, M, Lamarque, P, and Rouanet, J F, 1974, Datation absolue par la Thermoluminiescence. Etude d'une série d'échantillons d'origine archéologique dont deux fragments de grès brulés provenant de niveaux magdaléniens IV et VI: Acad sci [Paris] Comptes rendus, sér D, v 279, p 191-195.

Vuillaume, Y, 1972, Etude isotopique des eaux de la nappe de Aïn Beni Mathar, Maroc Oriental: Unpub rept BRGM, no. 72 SGN 350 AME, 29 p.

Weidmann, M, 1969, Le mammouth de Praz Rodet -Le brassus, Vaud): Soc Vaudoise sci nat Bull, v 70, no. 331, p 229-240.

de Vaud: Soc Vaudoise sci nat Bull, v 73, no. 334, p 9-18. 